\title{
Comparison of conventional and leafy maize silage hybrids in New Zealand dairy farm systems
}

\author{
R.J. DENSLEY ${ }^{1}$, E.S. KOLVER ${ }^{2}$, D.B. MILLER ${ }^{1}$, I.D. WILLIAMS ${ }^{1}$ and R. TSIMBA ${ }^{1}$ \\ ${ }^{I}$ Genetic Technologies Ltd, P.O. Box 105 303, Auckland \\ ${ }^{2}$ Dexcel, PB 3221, Hamilton \\ rdensley@genetic.co.nz
}

\begin{abstract}
This study compared the yield and nutritive content of conventional and leafy maize silage hybrids, and the expected differences in milksolids (MS) production if fed to cows. A range of conventional and leafy hybrids were planted in paired strip trials $(\mathrm{n}=162)$ or small plot trials ( $\mathrm{n}=132)$ during spring 1999, 2000, 2001, 2002, 2003 , and 2004 in all of the main maize silage growing areas from Nor thland to Canterbury. Pair ed comparisons of short, medium, and long maturity conventional and leafy hybrids were made. On average, conventional hybrids yielded $1824 \mathrm{~kg} \mathrm{DM} / \mathrm{ha}$ (9\%) more than leafy hybrids and had a marginally lower fibre digestibility (0.6 percentage units). Modelling using the Cornell Net Carbohydrate and Protein Systems (CNCPS) model showed that leafy hybrids had a similar metabolisable energy (ME) content and MS per cow and per tonne of maize silage were not different. For dairy farmers growing their own maize silage crop to feed to cows, the planting of conventional hybrids will result in more MS and profit/ ha of maize grown than will the planting of leafy hybrids. If maize silage is purchased on a cent $/ \mathrm{kg}$ dry matter (DM) basis, the small differences in nutritive content of leafy and conventional hybrids will not affect MS production or profit.
\end{abstract}

Keywords: dairy cows, leafy hybrids, maize silage yield, nutritive value

\section{Introduction}

The number of New Zealand dairy farmers using maize silage is increasing as is quantity used per farm (Kolver et al. 2001). New Zealand research has shown that there are large differences in the yield and small but statistically significant differences in the quality of different maize silage hybrids (Kolver et al. 2003). Since most of the costs associated with growing maize silage are fixed, yield has a large impact on the cost $/ \mathrm{kg}$ DM and ultimately profitability. Selecting the right hybrid is therefore an important part of the maize silage production process.

Internationally there are several different types of maize hybrids to consider for use as silage in dairy cow rations. Conventional hybrids are by far the most widely used and are suitable for either maize silage or grain production. Natural genetic variation in maize has been exploited to produce hybrids commonly referred to as maize types including waxy, high lysine, brown midrib, high oil, and leafy.

Leafy hybrids are characterised by more leaves above the cob. They have been commercially available in NZ for about five years. While they have been extensively evaluated for yield and in dairy total mixed rations (TMR) in the Northern Hemisphere, there has been no published evaluation of their performance under NZ conditions or when included in pasture-based dairy cow diets.

The objective of this study was to evaluate the yield, nutritive quality, MS production potential and profitability of conventional versus leafy maize silage hybrids in NZ pasture-based dairy systems.

\section{Materials and methods \\ Field testing}

A range of conventional and leafy maize silage hybrids were planted in strip trials $(\mathrm{n}=162)$ or small plot trials $(\mathrm{n}=132)$ during spring 1999, 2000, 2001, 2002, 2003 and 2004. Trials were conducted in all of the main maize silage growing regions from Northland to Canterbury. The hybrids planted in each trial were of a similar maturity. Not all hybrids were represented at each site and not all hybrids were represented in each year. The trials were planted in commercial maize silage paddocks on either dairy farms, maize silage cropping farms or at Pioneer ${ }^{\circledR}$ brand Maize Research Stations.

In strip trials, maize was planted in rows that were $76.2 \mathrm{~cm}$ apart using commercial maize planters. Each trial contained up to six hybrids with each hybrid strip consisting of four or six rows depending on the planter width. Strips were $100 \mathrm{~m}$ or more in length depending on the paddock size. In small plot trials maize was planted in rows that were $76.2 \mathrm{~cm}$ apart using a Wintersteiger maize small plot planter. Hybrids were allocated to plots using a split plot arrangement in a randomised complete block design. There were a total of three replicates per hybrid and the plot size was 2 rows wide x $5.3 \mathrm{~m}$ long. There were no guard rows within the trial but borders were planted around the outside to nullify edge effects.

All seed was insecticide treated with either Gaucho ${ }^{\circledR}$ or Poncho ${ }^{\mathbb{}}$ as per the industry norm for the planting year. Planting population was generally 100000 plants/ ha. The planting population was consistent for each hybrid in a trial. 


\section{Yield measurements}

Silage harvest took place when the hybrids were visually assessed (using kernel milk-line score) to be between $30-38 \%$ whole plant DM content.

For the strip trials, a uniform section of the crop was selected and the plants from three $5.3 \mathrm{~m}$ strips of one of the middle two rows of each hybrid were hand cut at 15 $\mathrm{cm}$ above ground level and weighed. A total of eighteen plants (six per strip) were chopped to provide a sample for DM determination. Small plot trials were mechanically harvested and weighed using a two-row maize silage small plot harvester.

A $1 \mathrm{~kg}$ sample of chopped whole plant maize was collected and dried at $62^{\circ} \mathrm{C}$ until constant weight. Dry, ground samples of the maize hybrids from the small plot trials were analysed by near-infrared spectroscopy (NIRS).

\section{Sample analysis}

Total DM yield was determined for each plot (three $5.3 \mathrm{~m}$ lengths) in both the strip and small plot trials. Each sample from each replicated small plot was analysed by NIRS for DM, acid detergent fibre (ADF), crude protein (CP), neutral detergent fibre (NDF), NDF digestibility (NDFD) and starch (Corson et al. 1999).

\section{Da ta Analysis}

To remove the confounding effects of a number of factors including year, loca tion, hybrid maturity, time of planting and time of harvest on DM yield, \% DM and nutritional parameters paired comparisons were made between conventional and leafy hybrids planted in the same trials.

Four paired comparisons were made using commercially available conventional and leafy hybrids of similar harvest maturity (as determined by a harvest DM difference of $+/-2.5 \%$ ).

The hybrid pairs (conventional vs. leafy) were Pioneer ${ }^{\circledR}$ brand $33 \mathrm{G} 26$ vs. Corson Tender Leafy ${ }^{\circledR}$ CTL108; Pioneer ${ }^{\circledR}$ brand 3522 vs. Corson Tender Leafy ${ }^{\circledR}$ CTL102; Pioneer ${ }^{\circledR}$ brand $36 \mathrm{H} 36$ vs. Corson Tender Leafy ${ }^{\circledR}$ CTL96 and Pioneer ${ }^{\circledR}$ brand 38 F70 vs. Corson Tender Leafy ${ }^{\circledR}$ CTL 90.

The comparative relative maturity (CRM) of the conventional hybrids was 112, 104, 100 and 93 for $33 \mathrm{G} 26,3522,36 \mathrm{H} 36$ and $38 \mathrm{~F} 70$ respectively. The CRM of the leafy hybrids was 108, 102, 96 and 90 for CTL108, CTL102, CTL96 and CTL90 respectively.

Starch yield/ha was calculated by multiplying starch $\%$ by total DM yield/ha.

Means from each of the 294 trials were calculated for each paired comparison. Data from each of the four hybrid pair comparisons was analysed individually using anal ysis of variance (Genstat $\mathrm{V}$ ) with trial as a blocking factor. The combined da ta were analysed by calculating the means of the 8 hybrids and using a paired t-test. Significant differences were declared at $\mathrm{P}<0.05$.

\section{Modelling}

To predict milk production in a pasture-based system from conventional or leafy hybrids, the CNCPS model was used (version 4.0.31). The CNCPS is the basis for the model released with the current Nutrient Requirements of Dairy Cattle (2001) and has been evaluated for pasture based diets (Kolver et al. 1998). The model uses mechanistic and empirical relationships to predict ME, metabolisable protein, amino acid and macro-mineral requirements of dairy cattle, and the supply of these components from the diet than from digested and absorbed feed sources. In particular the model can simulate interactions between feeds being digested in the rumen.

The base pasture diet and the milk production data used for the pasture-based maize silage evaluation was from observed data for a Friesian cow (470 kg liveweight) producing $2 \mathrm{~kg} \mathrm{MS} /$ day $(24.2 \mathrm{~kg}$ milk/day) in early lactation (57 days-in-milk), consuming $16.6 \mathrm{~kg} \mathrm{DM} /$ day of pasture and gaining $0.1 \mathrm{~kg}$ liveweight/day (Kolver $e t$ al. 2002). Pasture was assumed to be of a high quality (12.4 MJ ME/kg DM, 15\% DM, 41.9\% NDF, 29\% CP, $5.4 \%$ fat, $10.6 \%$ ash). For the other parameters required by the model, data from a high-quality pasture in the CNCPS library were used, including a carbohydrate B2 rate of $16 \% / \mathrm{h}$ (the ruminal degradation rate of fermentable fibre), a protein $\mathrm{B} 2$ rate of $22 \% / \mathrm{h}$ (the ruminal degradation rate of medium degradable protein) and an effective fibre content of 41 (\% of the NDF effective in stimulating chewing and salivation, rumination, and rumen motility). The model correctly predicted the milk production and liveweight change on the base pasture diet (data not shown).

To simulate the nutritional status of an average conventional or leafy hybrid, the average nutritional data from these trials were used (Table 2). The simulation compared the two hybrids when cows were fed a diet of $4 \mathrm{~kg}$ maize silage and $12.6 \mathrm{~kg}$ pasture $\mathrm{DM} / \mathrm{cow} /$ day. A diet with maize silage $24 \%$ of the cows DM intake is a level commonly used. (Kolver et al. 2001). The simulation used $50 \%$ grain maize silage with medium particle size (CNCPS library number 311 ) for the base maize silage. This silage contained 35\% DM, $8 \% \mathrm{CP}$, $41 \%$ NDF, $3.5 \%$ fat, and $43 \%$ non-fibre carbohydrate (calculated as $100-(\mathrm{CP}+\mathrm{NDF}+$ fat + ash $))$, which was very close to the mean of the conventional and leafy hybrids (Table 1, Table 2). The nutrient composition of the maize silage was changed according to the average of the two hybrids (Table 2). In addition, the value of effective fibre was increased from $71 \%$ of NDF to $87 \%$ of NDF to better reflect the level of maize silage 
Table 1 Yield (kg DM/ha) and harvest DM \% of conventional and leafy maize silage hybrids (harvest 20002005).

\begin{tabular}{lccccc}
\hline Hybrid & Hybrid type & No. observations & No. of years & Yield (kg DM/ha) & Harvest DM (\%) \\
\hline 33G26 & Conventional & 77 & 5 & 24779 & 32.7 \\
CTL108 & Leafy & 77 & 5 & 22035 & 34.4 \\
SED & & & 320 & 0.28 \\
P & & & 0.001 & 0.001 \\
3522 & Conventional & 55 & 4 & 22137 & 36.6 \\
CTL102 & Leafy & 55 & 4 & 20862 & 34.2 \\
SED & & & & 330 & 0.40 \\
P & & & 0.001 & 0.001 \\
36H36 & Conventional & 74 & 4 & 21423 & 34.6 \\
CTL96 & Leafy & 74 & 4 & 19658 & 35.4 \\
SED & & & & 360 & 0.45 \\
P & & & 0.001 & NS \\
38F70 & & 6 & 20720 & 35.4 \\
CTL90 & Conventional & & & 19207 & 34.4 \\
SED & Leafy & 88 & 6 & 280 & 0.32 \\
P & & & & 0.001 & 0.01 \\
Average & Conventional & 294 & - & 22265 & 34.8 \\
Average & Leafy & 294 & - & 20441 & 34.6 \\
SED & & & & 322 & 0.94 \\
P & & & & 0.01 & NS \\
\hline
\end{tabular}

Table 2 Nutrient composition (\% DM) of conventional and leafy maize silage hybrids.

\begin{tabular}{|c|c|c|c|c|c|c|c|}
\hline Hybrid & Hybrid type & No. observations & ADF & NDF & NDFD ( $\%$ NDF) & $\mathrm{CP}$ & Starch \\
\hline 33G26 & Conventional & 19 & 25.30 & 44.80 & 40.37 & 7.04 & 29.04 \\
\hline CTL108 & Leafy & 19 & 24.35 & 43.47 & 40.85 & 7.13 & 29.25 \\
\hline SED & & & 0.75 & 1.01 & 0.47 & 0.14 & 1.26 \\
\hline $\mathrm{P}<$ & & & NS & NS & NS & NS & NS \\
\hline 3522 & Conventional & 23 & 24.28 & 42.91 & 42.03 & 7.47 & 28.73 \\
\hline CTL100 & Leafy & 23 & 23.12 & 41.03 & 42.46 & 7.94 & 30.37 \\
\hline SED & & & 0.48 & 0.75 & 0.36 & 0.11 & 1.30 \\
\hline $\mathrm{P}<$ & & & 0.05 & 0.05 & NS & 0.001 & NS \\
\hline $36 \mathrm{H} 36$ & Conventional & 22 & 23.46 & 43.53 & 42.91 & 7.10 & 31.66 \\
\hline CTL96 & Leafy & 22 & 22.94 & 42.34 & 43.99 & 6.93 & 32.99 \\
\hline SED & & & 0.54 & 0.93 & 0.37 & 0.18 & 0.90 \\
\hline $\mathrm{P}<$ & & & NS & NS & 0.01 & NS & NS \\
\hline $38 F 70$ & Conventional & 18 & 23.10 & 41.41 & 42.34 & 7.38 & 29.68 \\
\hline CTL90 & Leafy & 18 & 23.60 & 42.40 & 42.64 & 8.01 & 27.78 \\
\hline SED & & & 0.81 & 1.27 & 0.50 & 0.15 & 1.76 \\
\hline $\mathrm{P}<$ & & & NS & NS & NS & 0.001 & NS \\
\hline Average & Conventional & 82 & 24.03 & 43.16 & 41.91 & 7.25 & 29.78 \\
\hline Average & Leafy & 82 & 23.50 & 42.31 & 42.48 & 7.50 & 30.10 \\
\hline SED & & & 0.37 & 0.63 & 0.17 & 0.18 & 0.80 \\
\hline $\mathrm{P}<$ & & & NS & NS & 0.05 & NS & NS \\
\hline
\end{tabular}

processing that occurs. (Kolver et al. 2001). The proportion of non-fibre carbohydrate present as starch was changed to reflect the starch values measured in Table 2. Ruminal degradation rate of carbohydrate (A $($ sugars $)=10 \% / \mathrm{h} ; \mathrm{B} 1(\mathrm{starch})=35 \% / \mathrm{h})$ and protein $(\mathrm{B} 1$ $($ rapidly degradable $)=300 \% / \mathrm{h} ; \mathrm{B} 2$ (medium degradable) $=15 \% / \mathrm{h} ; \mathrm{B} 3$ (slowly degradable) $=0.25 \% / \mathrm{h}$ ) were not altered between hybrids; however B2 carbohydrate (fibre) rate was changed to achieve the different digestible NDF values that were measured for the hybrids in Table 2 . This resulted in the $\mathrm{B} 2$ carbohydrate degradation rate being increased from the library value of $6 \% / \mathrm{h}$ to $6.15 \%$ / $\mathrm{h}$ (conventional hybrid) and $6.4 \% / \mathrm{h}$ (leafy hybrid).

A base pasture diet of pasture fed at $12.6 \mathrm{~kg} \mathrm{DM} / \mathrm{cow} /$ day was also simulated, and the difference in MS production between the restricted pasture diet and the 
Table 3 Predicted metabolisable (ME) and net energy ( $\mathrm{NE}_{L}$ content, $\mathrm{MS}$ production and MS income ${ }^{1}$ in response to feeding conventional or leafy maize silage hybrids at $4 \mathrm{~kg}$ maize silage DM/cow/day in early lactation ${ }^{2}$, based on simulations using the CNCPS model.

\begin{tabular}{|c|c|c|}
\hline & $\begin{array}{l}\text { Conventional } \\
4 \mathrm{~kg} \mathrm{DM/cow/day}\end{array}$ & $\begin{array}{c}\text { Leafy } \\
4 \mathrm{~kg} \mathrm{DM} / \mathrm{cow} / \text { day }\end{array}$ \\
\hline \multicolumn{3}{|l|}{ Energy content } \\
\hline $\mathrm{MJ} \mathrm{NE}_{1} / \mathrm{kg} \mathrm{DM}$ of maize silage & 7.0 & 7.1 \\
\hline MJ ME/kg DM of maize silage & 10.8 & 11.0 \\
\hline MJ NE $/ \mathrm{kg} \mathrm{DM}$ of total diet & 7.8 & 7.8 \\
\hline $\mathrm{MJ} \mathrm{ME} / \mathrm{kg} \mathrm{DM}$ of total diet & 12.1 & 12.1 \\
\hline \multicolumn{3}{|l|}{$\mathrm{MS}^{1}$} \\
\hline $\mathrm{kg} / \mathrm{cow} / \mathrm{day}$ & 2.11 & 2.11 \\
\hline $\mathrm{kg} / \mathrm{cow} /$ day due to maize silage & 0.66 & 0.66 \\
\hline $\mathrm{kg} / \mathrm{t}$ maize silage DM & 165 & 165 \\
\hline $\mathrm{kg} / \mathrm{ha}$ maize grown & 3674 & 3373 \\
\hline \multicolumn{3}{|l|}{ Milksolids income from maize silage } \\
\hline \$/t maize silage DM & 660 & 660 \\
\hline \$/ha maize silage grown & 14695 & 13491 \\
\hline
\end{tabular}

pasture/maize silage diet was considered to be the milk production attributable to the maize silage portion of the diet. This would represent a farm scenario in which stocking rate (cows/ha) was high, and pasture substitution rate was low. A key assumption is that both hybrids would result in a similar rate of pasture substitution.

\section{Results}

\section{Dry matter content (\% DM) and yield}

All of the hybrids had an average harvest DM\% between $32 \%$ and $37 \%$. The differences in \% DM were small with 33G26 (-1.7\%) being significantly wetter and 3522 $(2.4 \%)$ and 38 F70 (1.0\%) being significantly drier than their leafy counter parts (Table 1$)$.

Average maize silage yields of the conventional hybrids were between 20720 and $24779 \mathrm{~kg} \mathrm{DM} /$ ha compared with 19207 to $22035 \mathrm{~kg} \mathrm{DM} /$ ha for leafy hybrids (Table 1). In all four of the paired comparisons, conventional maize silage hybrids yielded significantly more (1275 to $2744 \mathrm{~kg} \mathrm{DM} / \mathrm{ha}$ ) than leafy hybrids.

A combined analysis of the 8 hybrid means showed the conventional hybrids on average yielded significantly more (1824 kg DM/ha) than leafy hybrids.

\section{Quality}

There was no significant difference in the starch content between hybrids.

Hybrid 3522 had a significantly higher NDF and ADF content, and significantly lower CP than CTL102. Hybrid 36H36 had a significantly lower NDFD than CTL96. Hybrid 38F70 had a significantly lower CP content than CTL90. All other hybrid comparisons of ADF, NDF,
NDFD and CP content were not significantly different (Table 2).

A combined analysis of the 8 hybrid means showed the conventional hybrids on average had a significantly lower NDFD, but did not differ in the content of NDF, ADF, CP or starch compared to leafy hybrids.

Conventional hybrids on average had a total starch yield of $6631 \mathrm{~kg} / \mathrm{DM} / \mathrm{ha}$ and leafy hybrids had a total starch yield of $6155 \mathrm{~kg} / \mathrm{DM} / \mathrm{h}$.

\section{Milk production}

The CNCPS model predicted leafy hybrids would have a small advantage in Net Energy Lactation $\left(\mathrm{NE}_{\mathrm{L}}\right.$ ) and $\mathrm{ME}$ content over conventional hybrids (Table 3). When fed at $4 \mathrm{~kg} \mathrm{DM} /$ cow/day, ME content of the total diet was not influenced by hybrid, and as a result MS production per cow and per tonne of maize silage DM was not different.

When hybrid yield was included in the calculation it was predicted that conventional hybrids would produce $301 \mathrm{~kg}$ more MS/ha of maize grown than would leafy hybrids when fed at $4 \mathrm{~kg}$ maize silage DM/cow/day.

Due to the consistent MS production/t of maize silage there was no difference between hybrids in MS income $/ \mathrm{t}$ of maize silage DM. However, conventional hybrids had an advantage of $\$ 1204 /$ ha of maize grown over leafy hybrids.

\section{Discussion}

Days from planting to harvest maturity is a critical consideration in the selection of maize silage hybrids since most farmers want to plant permanent pasture or a winter crop immediately after silage harvest. The CRM system ranks hybrids according to the amount of heat units required to reach harvest maturity. The CRM of a hybrid should give growers an indication of how long it will take to reach harvest maturity with higher CRM hybrids requiring more heat and taking more days to harvest than hybrids with lower CRM ratings. However CRM ratings are not uniform across commercial maize seed companies.

When harvested on the same day, CTL102 and CTL90 were $2.4 \%$ and $1.0 \%$ wetter than 3522 and 38 F 70 respectively despite the fact that the leafy hybrids had lower CRM ratings. CTL108 and CTL96 were only $1.7 \%$ and $0.8 \%$ drier than $33 \mathrm{G} 26$ and $36 \mathrm{H} 36$ respectively even though the leafy hybrids were 4 CRM lower in maturity. 
These data suggest that leafy hybrids are longer or conventional hybrids are shorter than their CRM ratings suggest. This has large commercial implications since a grower who chooses a hybrid that is too short in maturity will sacrifice yield potential and a grower who chooses a hybrid that is too long in maturity could face the dilemma of having to either harvest the crop too wet (resulting in DM yield and silage quality loss) or delay the sowing of a subsequent crop.

On average the conventional hybrids yielded $1824 \mathrm{~kg}$ $\mathrm{DM} /$ ha more than the leafy hybrids. Most of the costs associated with growing and harvesting maize silage are fixed therefore crop yield is the single variable that has the largest impact on maize silage cost $/ \mathrm{kg}$ DM. Assuming growing costs (spraying out pasture to side-dress nitrogen application and including interest) of $\$ 1952 / \mathrm{ha}$ the average growing cost for conventional hybrids was $8.8 \mathrm{c} / \mathrm{kg}$ DM and $9.5 \mathrm{c} / \mathrm{kg}$ DM for leafy hybrids.

There is a large volume of maize silage contract grown and sold on $\mathrm{c} / \mathrm{kg}$ DM basis to dairy farmers with the purchaser paying for harvesting and all subsequent costs. The standing price varies by district but is in the range $14-18 \mathrm{c} / \mathrm{kg}$ DM. Given the yield advantage to conventional hybrids, a contract grower who sold his crop for $15 \mathrm{c} / \mathrm{kg}$ DM standing would net $\$ 273$ more per hectare for an average conventional hybrid than an average leafy hybrid. To return the same per hectare as for a conventional hybrid, the grower would have to charge an extra $1.3 \mathrm{c} /$ $\mathrm{kg}$ DM for a leafy hybrid.

In the current study the small difference in fibre digestibility of conventional and leafy hybrids had no effect on milk production. But when the yield advantage of conventional hybrids was accounted for, conventional hybrids produced more MS and greater MS income per ha of maize grown than leafy hybrids. Recent research has shown that in NZ dairy systems, hybrid yield has a much higher impact on milk production than hybrid quality (Kolver et al. 2003). This confirms that providing maize silage is of reasonable quality, greater MS gains will be obtained by growing maize crops with higher yields than by achieving small changes in nutrient composition.

This outcome is consistent with overseas dairy trials. There have been seven published trials that have made a total of nine comparisons between leafy and conventional maize silage in the rations of high producing dairy cows. Of the nine hybrid comparisons, six showed no difference for milk yield when corrected for animal liveweight (Ballard et al. 2001; Block et al. 1998; Chase. 2000; Kuehnet al. 1999; Nennichet al. 2003; Bal et al. 2000). Two comparisons showed that the leafy hybrid produced more milk (Block et al. 1998; Clark et al. 2002) and one comparison showed the leafy hybrid produced less milk (Ballard et al. 2001) than the conventional hybrid. All nine of the comparisons showed no difference for milk fat $\%$ for leafy vs. conventional maize silage. One comparison (Chase 2000) showed that leafy silage increased milk protein $\%$ while all other trials showed no difference between hybrids on milk protein $\%$.

The dairy farmer growing maize silage on-farm must consider the total milk production potential of a maize silage hybrid, including how many kg DM it delivers as well as the milk production potential/kg DM. For an economic analysis, the financial implications of planting conventional versus leafy hybrids were considered. In 2000, Waikato dairy farmers that grew maize on-farm planted an average of $4 \mathrm{ha} /$ year (Kolver et al. 2001). Assuming similar planting costs between hybrids, these farms would make an additional $\$ 4816$ in farm profit by using a conventional instead of leafy hybrid.

\section{Conclusion}

For farmers growing their own maize silage crop, planting conventional hybrids will result in higher DM yields, MS and profit/ha of maize grown when fed to dairy cows compared to leafy hybrids. If maize silage is purchased, differences in nutritive value of leafy and conventional hybrids do not affect MS production and profits.

\section{ACKNOWLEDGEMENTS}

The authors would like to thank the Pioneer research team who provided substantial technical assistance, Angela Land for data entry and Brian Meece, Pioneer Hi-Bred International and Barbara Dow, Dexcel for statistical analysis.

\section{REFERENCES}

Bal, M.A.; Shaver, R.D.; Al-Jobeile, H.; Coors, J.G.; Lauer, J.G. 2000. Corn silage hybrid effects on intake, digestion and milk production by dairy cows. Journal of Dairy Science 83: 2849-2858.

Ballard, C.S.; Thomas, E.D.; Tsang, D.S.; Mandebvu, P.; Sniffen, C.J.; Endres, M.I.; Carter, M.P. 2001. Effect of corn silage hybrid on dry matter yield, nutrient composition, in vitro digestion, intake by dairy heifers, and milk production by dairy cows. Journal of Dairy Science 84: 442-452.

Block, E. ; Carreno, J.; Tremblay, E. 1998. Evaluation of the TMF (Mycogen Seed) variety of silage corn for lactating dairy cattle. https://upload/mcgill.ca/animal/ 98r09.pdf.

Chase, L.E. 2000. Effect of corn silage hybrid on feed intake, milk production and digestibility in lactating dairy cows. Dairy Nutrition Fact Sheet 17/7/00. Cornell University, USA.

Clark, P.W.; Kelm, S.; Endres, M.I. 2002. Effect of feeding a corn hybrid selected for leafiness as silage 
or grain to lactating dairy cattle. Journal of Dairy Science 85: 607-612.

Corson,D.C.; Waghorn,G.C.; Ulyatt, M.J.; Lee, J. 1999. NIRS: Forage analysis and livestock feeding. Proceedings of the New Zealand Grassland Association 61: 127-132.

Genstat V. 1997. Genstat 5, Release 4.1, Reference Manual. Oxford University Press, Oxford, UK.

Kolver, E.S.; Densley, R.; Miller D.; Williams, I.; Sapienza, D. 2003. Ranking maize hybrids for silage quality and milk production in pasture-based dairying. Proceedings of the New Zealand Society of Animal Production 63: 101-106.

Kolver, E.S.; Muller, L.D.; Barry, M.C.; Penno, J.W. 1998. Evaluation and application of the Cornell Net Carbohydrate and Protein System for dairy cows fed diets based on pasture. Journal of Dairy Science 81: 2029-2039.

Kolver, E.S.; Roche, J.R.; Miller, D.; Densley, R. 2001.
Maize silage for dairy cows. Proceedings of the New Zealand Grassland Association 63: 195-201.

Kolver, E.S.; Roche, J.R.; de Veth, M.J.; Napper, A.R. 2002. Total mixed rations versus pasture diets: Evidence for a genotype $\mathrm{x}$ diet interaction in dairy cow performance. Proceedings of the New Zealand Society of Animal Production 62: 246-251.

Kuehn, C.S.; Linn, J.G.; Johnson, D.G.; Jung, H.G.; Endres, M.I. 1999. Effect of feeding silages from corn hybrids selected for leafiness or grain to lactating dairy cattle. Journal of Dairy Science 82: 2746-2755.

National Research Council. 2001. Nutrient Requirements of Dairy Cattle 7th revised edition. National Academy of Science. Washington DC, USA.

Nennich, T.D.; Linn, J.G.; Johnson,D .G.; Endres, M.I.; Jung, H.G. 2003. Comparison of feeding corn silages from leafy or conventional corn hybrids to lactating dairy cows. Journal of Dairy Science 86: 2932-2939. 